\title{
THE IDENTITY OF BUGIS-MAKASSAR CULTURE IN MARRIAGE- DISCOURSE ANALYSIS OF UANG PANAI' FILM
}

\author{
Nur Asia T. \\ Ms., University of Indonesia, INDONESIA, nursyifa.kpi@gmail.com \\ Drs. Eduard Lukman., MA
}

\begin{abstract}
Every culture and nation has a wisdom and special identity. Indonesia has many ethnics which is spreaded from Sabang to Merauke. One of the biggest ethnics is Bugis-Makassar located in South Sulawesi province. Culture of Marriage on this ethnic is different with other ethnic. Before marriage, there are many traditions that should be involved. One of them is Uang Pana'i where two family, both brides and grooms' family, set the amount of money that the groom family should give to the bride family as "uang panai' ".in this time, the function of the tradition have changed as shape of one's wealth to show their status in society. Researcher tried to reveal a shift in this tradition. Researcher used discourse analysis to reveal it. The Object used in this research is a film entitle " Uang Panai' " Mahar $(L)$. The meaning of Mahar is dowry and the meaning of mahal is expensive. Actually "Uang Panai' " is not like Mahar. There is different between them, but generally people do not know about that. In this film we know how about " Uang Panai' " have influence in society and impact to their life. There are some things that explain that Uang Panai is used as a tool to show a person's prestige to show that they are more deserving of higher honors than others. The higher the level of education, degree, and social status then the money given as " Uang panai' " must also be greater. This is part of the unwritten rule. A consideration is needed to minimize the consequences of the high "Uang Panai"" desired by the bride family.
\end{abstract}

Keywords: Cultural Identity, culture of marriage, discourse analysis

\section{BACKGROUND}

Plural society constantly seeks to accept changes in social conditions that are faced with the fact that there is a shift in cultural values causing the eroded identity. The cultural identity of the people, both individually and socially, is influenced by the changes. For the sake of maintaining the cultural values, people or traditional leaders use customary norm system which is intended for all local people who trust the rule. Existing norms and custom values are used to perpetuate custom or become a tool that binds the people. Various events are influenced by the strong role of custom such as in marriage event, ritual activities and even death. Customs have functions and values adapted to society. 
The values and functions of custom are changing so as to trigger conflict among the communities that carry out the custom itself (Littlejohn \& Domenici, 2007). Behavior changes, mindset and higher education make the existing groups have different understanding about the custom. They experienced a period of distrust to the custom institution which ended badly on an event that influenced a particular group of people (Littlejohn \& Domenici, 2007). In addition, different societal groups of social class have different rules from each other. The higher the social class of the group or people, the greater the values, rules and customs that must be implemented (Griffin, 2012).

Custom as part of the culture that binds the people to obey and live is often misunderstood and it leads to conflict both as individuals and groups in society (Martin \& Nakayama). The culture of each region that is different from each other tends to highlight its own advantages. Cultural identity tends to give its own form to the culture of the people (Martin \& Nakayama, 2007). In addition, cultural identity tends to be bumped by certain groups with religious identity, resulting in a lesser conflict. The highlighted cultural identity will lead to an imbalance in the social group from outsider.

In the paradigm of Peter D. Moss (1999), the discourse of mass media is the resulting cultural construct is ideology because as a mass media product, the mass media uses a certain framework to understand social reality. The mass media offers certain definitions of human life: who is the hero and who the bad, the good and the bad, the decent and the unworthy (Eriyanto, 2002: 10). Society as a form of social reality becomes very vulnerable to its environment. Their identity then becomes something that simultaneously blends and adapts to the social conditions of society.

In its development, culture as part of the society strives to be preserved and preserved. Culture is communicated to the generation of peers to be understood and preserved, but it is not possible, the culture in this case the customs and other things can be reconstructed even differently than before if the communication is not appropriate. As said by Edward T Hall that communication is culture and culture is communication.

One of the characteristics and characteristics of culture is more likely to be the identity and cultural value contained. In a plural society, tolerance becomes one of the most important parts to adapt to the environment, respect for others and adaptation. Surely this is not dismissed simply by seeing that everyone has had a tendency to bring a certain value or identity to a particular early verse. Communities forged with strong indigenous cultures are certainly different from those who have been accustomed to living independently and freely.

Bugis-Makassar society embraces high cultural values and is known as Siri na Pesse. This value is embedded to explain how to maintain the principle of life and form self-concept based on upholding selfesteem (Keeping Embarrassment) and Empathy towards others. These two cultural values are embedded into unity in the conduct of everyday life. In addition, in Lontara La Toa explained that there are at least about 1000 suggestions or messages. Among them there are 5 important tips that are destined for the next generation that is 1) Ada Tongeng that everyone should say true, 2) Lempu, which means to maintain honesty, 3) getteng, cling to the principles of belief, 4) Sipakatau which means mutual respect for humans, 5) Mappesona ri Dewata Seuwae is resigned to Allah the Almighty God. These five tips serve as a foundation in shaping the value of Siri 'na Pesse, known as the life philosophy of Bugis-Makassar society (Pemelleri, 2006)

Today the culture is growing and beginning to experience reconstructions of meaning that are different from each other. Media is not separated from its role as cultural socialization agent. One of the media that can attract many people is the film. The film as a picture of a reality becomes very close to the condition of society. Through the film, the audience can be drawn to participate emotionally feel the message delivered. Messages delivered through the film can be interpreted variously. Film as a representation of reality tries to accentuate things including certain cultures. However, cultures are beginning to change according to the interests of social and cultural actors. Similarly, in films with a cultural theme, serve as one of the tools to manipulate and show the existing cultural problems.

The panoramic film can be understood as a film that tries to highlight the theme or 'Uang Panai' culture or tradition featured in this 120 minutes duration featuring the story of a young man struggling to collect money for his idol. Stories that highlight the social conditions of the Bugis-Makassar community, are colored by an intriguing local humor. Many things that try to be explained through the film include the customs that must be met and the challenges faced in proposing Bugis-Makassar women. Bugis-Makassar community identities try to highlight with their cultural values. 


\subsection{Representation}

Representation is understood as a picture of something that is accurate or distorted reality. Representation does not just mean "to present", "to image", or "to depict" but also to stand in for, to speak or act on behalf of, and to re-present (Giles, 1999). Then, the political picture is present to represent us. These two ideas stand together to explain the idea of representation. "Representation" is a way in which to interpret what is given to the object described. The old concept of representation is based on the premise that there is a representation gap explaining the difference between the meaning of the representation and the meaning of the actual object. Contrary to that standard understanding, Stuart Hall argues that representation must be understood from the active and creative role of the person to frame the world.

$"$... so the representation is the way in which the meaning is somehow the things that are depressed through the images or whatever it is" on stand for what we're talking about. "(Hall, 1997)

Hall suggests that an image will have a different meaning and there is no guarantee that the image will function or work as they are created. Hall mentions "Representation as constitutive". Representation will not be present until it has been represented or the representation does not occur after an event. Representation is constitutive of an event. Representation is part of the object itself, it is constitutive of it (Hall, 1997).

\subsection{Cultural Identity}

Cultural identity not only provides a general picture but also a special characteristic that exists and has by society or certain social group. Culture is a result of construction that has been attached to a particular group of people and has become the identity of the people (Martin \& Nakayama, 2007). Owned identity can be demonstrated through various devices and norms including language (Neulip, 2015).

Language is the medium that mediates us in meaning something, producing and changing meaning (Martin \& Nakayama, 2007). The language can do all this because it operates as a representational system. Through language (symbols and written, oral, or pictorial marks) we express our thoughts, concepts, and ideas about something. The meaning of something depends on how we 'represent it'. By observing the words, we use and the images we use in representing things can be seen clearly the values we give to them.

Makassar's cultural identity is identical with Bugis-Makassar's values and philosophy. The value in question is Siri naPesse with the philosophy of life that supports it is, 1) Ada Tongeng that everyone should say true, 2) Lempu, which means to maintain honesty, 3) getteng, cling to the principles of belief, 4) Sipakatau which means mutual respect for humans, 5) Mappesona ri Dewata Seuwae is resigned to Allah the Almighty God. These five tips serve as a foundation in shaping the value of Siri 'na Pesse, known as the life philosophy of Bugis-Makassar society (Pemelleri, 2006)

\subsection{Film}

Film is one of the entertainment media that is popular enough to introduce and socialize various things (Effendy, 2000). Most viewers who enjoy the movie will certainly always feel the pleasure of the movie when the film touches the side of his life. The movie is different from other audiovisual media because it displays a different identity or forms another identity of the displayed storyline. Culture is an integral part of the film. Culture is one of the products in the production of film and became one of the themes of the film (Marchetty \& Tan See Kam, 2007).

Film as a cultural representation gives us the understanding that the film gives us a picture of a culture whether it is local, national, or international. Various films appear and provide different essences depending on the proximity of the film with the audience (Mc Quail, 2011). Movies that highlight local cultural themes are often enjoyed by local people who are part of the theme. One of the local theme films is about Wedding Culture of Bugis-Makassar entitle "Uang Pana'i". It gives various images about the people not only about marriage but also friendship, local culture in the form of songs and language. This film provides an overview of the use of the local language of Bugis-Makassar people and the mixing of Indonesian and regional languages in every dialogue.

\subsection{Case Description}

Cultural identity as something inherent in certain cultures, both national and local, often undergo adaptation and construct simultaneously and continuously. The existence of a social group that maintains a culture becomes a real means of objectivization which is then internalized by existing group then being applied. Those who make a culture as identity start to use the media both conventional and new media to do the movement so that the cultural identity can be maintained. One of the media that can be used is entertainment media in this case is film. 
Cultural identity both local and national culture embodied in a film often describes the condition of the people to attract the public's attention. Film is a persuasive mean and effective socialization to develop the horizon of knowledge and insight. Film is an effective socialization tool that introduces culture and is used to defend culture as identity.

Film packs culture as a product to introduce to audiences about the identity of a local people or vice versa to give emphasis to people belonging to cultural groups. The number of films that uses the cultural theme we often find but it has not given maximal results. The tendency of movie lovers only to find entertainment without understanding the essence behind the existing film. In fact, now the film with local cultural concept of the area began lifted although it does not receive a big attention than the film is still struggling with the life of a big city or something like that.

Some regional films that try and translucent in Cinemas include "Uang Pana'i" film which was launched in 2016. This film produced by Makkita Cinema Production film reached 400ribu number of spectators spread in XXI or 21 cinema, CGV theaters in the country (Rakyatku.com). The theme film about Culture gives us the idea that Bugis-Makassar society has a very strong custom when determining the groom's candidate for his daughter.

\subsubsection{Sinopsis Movie Uang Panai'}

Film with the background of life of Bugis-Makassar is presented with a thick regional language. The movie "Uang Panai" tells about the dowry before being married from the Bugis-Makassar or can be called the "Uang Panai "'. In this film will be told how the struggle of a man when wanting to marry Bugis Makassar girl whose condition must fulfill some Money Panai. Briefly synopsis of Money Panai film is a story of a young man named Anca who fought for his love with full sincerity, to the woman her idol named Risna. Unfortunately, the customs rules of Bugis-Makassar tribe, requires Anca to pay the money as much as Rp 120 million when He wants to marry for his girlfriend. Some conflicts arise such as Anca's misery in raising money 'and the presence of a third person in their relationship. Misunderstandings between Anca and Risna and behaviour of Abu and Tumming giving comedy and humorious in this film. The self-esteem of a BugisMakassar Man became the protrusion in this film. Anca as a Man have to give monye for the brides party and Risna's parents as a noble class have a high demanding.

\section{SEQUENCE AND THEMES ANALYSIS}

The analysis method used is sequence analysis and theme analysis which is part of discourse analysis. According to Aumont and Marie (2004, p.36), sequences are a narrative unit within a period in the film. Analyzing sequences is a mandatory stage when performing film analysis (Aumont and Marie, 2004, p 37). They explained that there are two elements in the sequences to be analyzed, namely the image element (bande image) and the sound element (bande sonore). The image elements include shot, camera movement, lighting, scene and time, character position in frame, and dominant color (visible from light color or clothing worn by character). Meanwhile, the sound elements include the dialogue and background music used (Aumont and Marie, 2004 p.40).

Furthermore, in analyzing the theme of Boggs and Petrie (2012, p.18) mentions four elements to note:

1. Plot: the plot is usually the most important part for films with action or adventure genres. Movies that prioritize the plot elements as theme builders, will usually pay great attention to the cause-and-effect relationship and the significance of any action or event in the story (Boggs and Petrie, 2012, p.18).

2. Emotional or mood effects: Emotional-focused films focus on the emotional impact that occurs on the character after an event occurs. However, audience emotion can also serve as a target for filmmakers, and it is commonly used in horror and / or comedy movies.

3. Character: Many directors or filmmakers make at least one character as the core of the story. The focus of these films is how the main character develops in various aspects, from the physical to the mental and emotional. The character element is usually very important in biopic films.

4. Film style or texture: This element deals with the cinematographic aspects and / or structure of the story. Some film genres such as science fiction, and animation prioritize this aspect in building the story. For example, the Pulp Fiction (1994) film has an unusual story structure, because the story is divided into sections, and the sections are randomized, so the audience will have difficulty determining the beginning and ending of the story. 


\section{DISCUSSION}

The film "Uang panai" is one of the films that raised the theme of culture, the film with the background of adat and social reality of the Bugis-Makassar people. Exclusively presents a dialogue with local and Indonesian language with local dialect. This film outlines the social life urban areas in the city of Makassar and the reality of young people. Video with a background of the city of Makassar which has a theme that is quite sensitive is the issue of "Uang Panal" is expensive and continuously increasing in number as well as debates about values and religion as a consideration of indigenous sustainability. This film consists of 66 Sequence can be analyzed by using the concept of Bugis-Makassar Cultural value, but not all sequences can show the value.

\subsection{The concept of Bugis-Makassar Cultural Values}

Siri 'napasse as Bugis-Makassar community value is also emphasized in several dialogues showing that the film is trying to accentuate their values and identity as Bugis-Makassar people. As in the sequences 4, 12, $16,19.23,34,36,37,40,41,49,53,58,59-62,66$.

\section{Siri 'Sign:}

- Anca and Risna meet again, but Risna feels angry at Anca

- Anca is looking for work in several companies

- Anca who feels humiliated when Risna gives her Necklace to supplement '

- Risna's father who feels humiliated when Risna and Anca intend to Kawin Lari

- Risna's father who does not want to ask his friend for help to repay his debt to the debt collector

- Anca who promises to fulfill the requested sum of money and will not set foot in Rumah Risna before the money is collected

\section{Siri' Object:}

- Anca looking for Risna's social media account

- Anca who seeks to collect the requested harvest money

- Risna's father who forcibly pulled Risna and drove her home

- Risna's father requested additional time on the debt collector in repayment of his debt

- Anca chooses to decide Risna

- Anca who returns home Risna to apologize

\section{Pesse's Sign:}

- Anca who captured the snatcher

- Abu and Tumming that help Anca find work on the newspaper page

- Abu and Tumming who seek donations to help Anca collect Uang Panai' '

- Anca apologizes and asks for a second chance to Risna's Father

- Anca paid Risna's Father debt.

\section{Passe Object:}

- Anca returns the bag in the jambret to the owner who turns out to be Risna

- Anca who is looking for a suitable job based on job vacancy in the Newspaper

- Anca thanks Abu and Tumming

- Anca is trying to hook potential customers who previously decided the contract because of disappointment with Anca

- Risna's Father finally gave Anca and Risna blessing.

\section{Interpretation}

In the 4th sequence, Anca and Risna met again after the long separation, accompanied by the mugging event experienced by Risna and anca who managed to bring back Risna Bag, although knowing each other 
Risna who still feel hurt did not say thank you. There is still pride in his heart towards Anca. And Anca who was quite happy to meet Risna back.

In the 12th sequence, Anca decided to look for a job, Anca, Abu and Tumming started looking for a job available on the Job Opportunity page of the Newspaper, yet when Anca started her search for a job she had not been accepted in one company after visiting several companies. This indicates that Anca is struggling to find a job.

In Sequence 34. Mrs. Risna and her family gathered in the living room talking about the Anca family who was coming to apply. Questions arise from the Risna's family about who is proposed and who is applying, whose children, what jobs they are, where they are from, bugis or not, bachelor or not, whether or not they are haji or not. Risna comes bringing drinks to the mothers. The first mother said that when her son married the amount of his 75 million dollars, the dowry was 50 grams of gold, the rice fields of one plot, and bore the rice eaten when the wedding reception at the bride's house was carried out. The scene ends with Do not forget the Erang-erangnya (Seserahan). This shows how family background is very important as a consideration in carrying out marriage

In Sequence 37, Risna and Farhan meetings on the Golf course with their father. Risna's father told him about the problem he was facing but did not want to ask his friend for help.

In the 41st sequence where Tumming gives spirit to Anca and says "Paentengngi Siri'nu" which means keep your pride. As a man. This indicates that a man has an important role that should not be easy to follow Asa.

Sequence 53, Risna who gave Gold Necklace to Anca through Abu and tumming but Anca refused and returned to Risna, Anca felt humbled for not being able to fulfill the amount of Uang Panai' 'requested. End with their quarrel. This indicates that Anca has different views and feels that her self-esteem is hurt if she is unable to provide the money.

Sequence 58, Risna's father dragged Risna Pulang. He feels in disgrace with the intention of Risna and Anca to elope. The Unblessed marriage as a shortcut that Risna wants to do because the cAbu is not enough even though Anca is finally blamed

Sequence 59, Anca Boss Advising Anca As a Bugis man to apologize to the Risna family and to strive to return to collect Uang Panai', with Sentence; the first Screen exposed to a tidal bite to the beach (Sekali layar Terkembang Pantang Biduk Surut ke Pantai), meaning as a Bugis-Makassar Man abstinence to retreat and surrender.

Sequence 60, Anca visits in front of Rumah Risna, on the stairs He apologizes and promises to come back when his Panai's money has been collected. He said that he was the one who clung to the phrase "taro no taro promise" and will not meet Risna until the money is collected.

\subsection{Uang Panai' and Dowry/ Mahar}

In the sequence of 36, Anca's family gathered and discussed about "Uang Panai' that the Risna family had requested. Anca's Mother is Anxious about Anca's ability to fulfill, And Anca's father is trying to be wise while explaining that in the past, "uang panai" is understood as a form of appreciation to a prospective bride who does not need to be mentioned in number. The mother who said that the "Uang Panai" every year increases and according to them made a prestigious event. Anca's father again explained that in Islam comprehension that in Marriage's duty is a dowry. And Dowry is not Uang Panai". Uang panai 'in the set to seek a wedding in the family home of women (Brides) who are also paid by the man (groom).

Uang panai is a duty. The woman in Bugis Makassar have a price. In Sequence 53, Risna said that you are not pride but that will be pride is me, because I have prise tag that is 120 Million rupiah. Risna is so sarcasm about the uang Panai because her marriage is not celebrated if it is not paid by Anca

Sequence 60 Risna's father attracts Risna and takes him home and says that you are cheeking off your parents, lowering their self-esteem. And left her in the room with her sister. Risna's father met a guest. Risna's father and his guest talked and apologized for the previous problem and then explained that Risna was having trouble with someone who had wanted to marry her but was plagued with Uang Panai' '. The guest commented that the Uang Panai' is currently a social problem causing elopement and high number of spinster. In addition, the guest explained that actually, marriege is one of the sunnah of the prophet. Both parents have an obligation to marry their offspring but if they require Uang panai' in the high means that he is blocking the obligatory obligations that he should perform.

Sequence 66, finally Risna's Father giving bless for Anca and Risna, high duty is not a problem again because Anca Have proved their seriousness for Marrying Risna. 


\subsection{Theme Analysis}

\subsubsection{Plot}

In the movie in the picture coat and use the Forward Ground. Setting location in Makassar city, in the form of Port, fly over, Highway, Anca Residence, Risna residence, Mall, small shop and Cafe described various events. The plot established from the arrival of Anca back to Makassar, his meeting with the risna again, the relationship is re-established, the desire Anca to propose Risna, efforts to collect money and get the blessing. Conflict in the story colors the various paths. In all sequence Risna and Anca make a plot is complex. Like sequence 1 for the opening that Anca Arrive in Makassar. Abu and Tumming are looking for Anca in harbor. The complexity of this film starts in sequence 34 that Risna want Anca to marry Her, She wants him to come in her house and meet her parents. The third people in Anca \& Risna Relationship in 45 and the fighting between Anca and Risna.

\subsubsection{Emotional or mood effect}

This film gives an emotional effect to those close to similar social conditions that generally are BugisMakassar people. The use of regional languages gives more effect to the local audience compared to other audiences. The effects on display tend to be romantic and humorous. Tumming and Abu gave humor color in the film. As well as the story of Risna and Ancha gave Romantic Effect. This is so dramatic that Risna And Anca try to unblessed Marriage, how to Risna refuse other man who want married her because she loves Anca.

\subsubsection{Characters}

In this film use many characters, starting main character Anca and Risna, Supporting characters: Abu, Tumming, Anca's parents and Risna's parents, Mita, farhan, and Rifki. Then the special guest is Jane Shalimar. Risna and Anca as main characters are Bugis-Makassar people who live in custom society where they have to follow the customs. Anca and Risna as a main character is so self-esteem. They want another will do their hope, like in sequence 53 Anca and Risna fight because Anca will not get necklace from Risna, because it is hurt his pride, and Risna is so sarcasm about Anca's pride. Abu and Tumming in all chance try to give humor in the dialog. They are Anca's friend and they are so solidarity with Anca. Like in Sequence 49 that Abu and Tumming are looking for additional Money for Giving it Anca' uang Panai.

\subsubsection{Film Style or Texture}

This film gives a pretty good effect and enrichment and mostly comes from the center light. Some backgrounds are taken during the day. Although there are some night backgrounds but still using natural lighting, such as home lights, car lights and other flickering lights. The lights are enough. All of sequences in the different place and different times. When the nights, spots are in the rooms or café or anyplace having source lights. The places like Anca's House, Anca's Room, Risna's house, Risna's Room, café, Company, Harbor, Roadway, and others.

\section{CONCLUSION}

A film depicting cultural identity is never independent from existing cultural values. Identity is as an integral part of people groups. Communities tend to prioritize their cultural and customary values resulting in more serious social problems. The film has a role as a medium for conveying and socializing cultural, social and identity values in order to avoid more complicated issues. Film as a cultural representation presents many things including the existing languages, religions and customary norms so that the film will provide an overview of the cultural identity that exists.

Cultural identity as part of the film is constructed in accordance with the role the film takes as a shaper or retain the existing culture. Movie lovers who are part of the involved group will have greater emotional attachment to the film being lifted. Local culture have disintegrate with the social change when it forced culture imperialism. The young of people can accept if the culture can be integration with the social change and how to use any media can represent it. This is not just for the people involved of the one culture but also for the people who are in the area, this is so function to reduct the uncertainty between two people in different culture. In addition, social group have a function to manage conflict it before been destruction.

The film "Uang panai' provides an overview of the social conditions of the Bugis-Makassar people about their customs and culture. This film explains the value of Siri 'na pass as the life principle of Bugis Makassar people. In addition, the philosophy of life Bugis-Makassar people try to present in this film. The film also tries to raise the issue and the result of the high "uang panai'. The problem in society of Bugis-Makassar, like ublessed marriage, and spinster. More than it, In religion like Islam, Marriage is a ritual and the duty of its is 
Dowry not "Uang Panai'”. This film is not only for Bugis-Makassar people but also for another who interest the culture of Bugis-Makassar. In this film many wise words from the local culture, it is show their local wisdom.

\section{ACKNOWLEDGEMENT}

I would like to thanks to my co-authors, Drs. Eduard Lukman., MA as adviser, teacher and parent for me. Especially for Dr. Udi Rusadi., MSi and Dr. Eriyanto., MSi will be ready to be my reviewer for this paper. My classmate in Magister communication science thanks for your support.

I would also to thank to my sponsorship for release me to follow the International conference, LPDP Scholarship to give me accommodation for the International conference.

This paper special for my family, specially my Father, Muhammad Nur and my mom, Almarhumah Maryam. I hope they are always happy and proud of me.

\section{REFERENCE LIST}

Aumont, Jacques dan Michel Marie. (2004). Analisis del Filme.

Boggs, Joe and Dennis Petrie. (2012). The Art of Watcing Films. McGraw-Hill Connect Learn Succeed

Effendy, Onong Uchjana. (2000). IImu, Teori dan Filsafat Komunikasi. Bandung: PT. Citra Aditya Bakti

Fiske, John. (1990). Introduction to Communication Studies 2nd edition. London: Routledge.

Giles, Judy. ( 1999). Studying Culture: A Practical Introduction. USA:Blackwell Publishing

Golan, Maerwyn, 2016.Ketika Cinta Terbentur Uang Mahar. https://posfilm.com/sinopsis-film-uang-panai2016-ketika-cinta-terbentur-uang-mahar/

Griffin, Em. (2012). A First Look at Communication Theory Fifth Edition. Boston: McGraw-Hill Higher Education.

Hall, Stuart. ( 1997). Representation: Cultural Representation and Signifying Practices. New Delhi : Sage Publication

James W. Neulip. (2015). Intercultural Communication, A Contextual Approach 6th edition. Los Angeles: Sage Publication.

Littlejohn, Stephen W. (2001). Theories of Human Communication 7th Edition. Mexico: Wadsworth

Littlejohn, Stephen W., and Kathy Domenici. (2007). Communication Conflict, and the Management of Difference. USA: Waveland Press

Marchetti, Gina and Tan See Kam. (2007). Hong Kong Film, Hollywood and the New Global Cinema No film is an island. New York: Routledge

Martin, Judith N., dan Thomas K Nakayama. (2007). Intercultural Communication in Context 4th Edition. New York: McGraw-Hill

McQuail, Denis. (2010). Mass Communication Theory $6^{\text {th }}$ Edition. USA: SAGE Publication. (2011). Teori Komunikasi Massa. Jakarta: Salemba Humanika.

Matullada, Hamid A, et al. 2007. Siri \&Pesse: Haraga diri Manusia Bugis Makassar Mandar Toraja. Makassar: Pustaka Refleksi.

Mulyadi Abdillah. (2016). Sedikit lagi, Film Uang Panai' Tembus 400 Ribu Penonton. Rakyatku.com. http://hiburan.rakyatku.com/read/20228/2016/09/10/sedikit-lagi-film-uang-panai-tembus-400-ribupenonton

Pamalleri, A. 2006. Riwayat Kabupaten Bone Makassar.

Pelras, Christian. 1996. The Bugis. USA: Blackwell Publisher.

Sobur, Alex. 2004. Semiotika Komunikasi. Bandung: Rosdakarya.

2006. Analisis Teks Media: Suatu Pengantar untuk analisis Wacana, Analisis Semiotika, dan Analisis Framing. Edisi Keempat. Bandung: PT Remaja Rosdakarya. 